\title{
EVALUASI PROGRAM KAWASAN RUMAH PANGAN LESTARI (KRPL) DI DESA MEKAR SARI KECAMATAN SERAWAI KABUPATEN SINTANG
}

\section{NIKEN PUSPITA RINI'), EVA DOLOROSA²), DEWI KURNIATI²)}

\author{
1) Jurusan Sosial Ekonomi Pertanian \\ 2) Jurusan Sosial Ekonomi Pertanian \\ Email : Puspitarini2210@gmail.com
}

\begin{abstract}
Food Security is the condition of the fulfillment of food for every household with the availability of good enough food in quantity and quality safe, evenly and affordably. The existence of the land yanag increasingly narrower the area of agricultural land diminishing, so that the management of agricultural resources that can provide benefits and contribute income households farmers is by empowering the field of nesting. This study aims to determine the type of crops cultivated, how much production and contribution or contribution of production from farming business on the income of farm households, malalui direct observation. The results showed that the KRPL program is a set of several households and utilized the keralan for five vegetable commodities namely kale, mustard greens, spinach, chilli and tomato. Household management and farming production in the Sustainable Food House (KRPL) program in Mekar Sari Village is quite good to be seen from the additional income of farmers of the KRPL program for family welfare and contributes $14,87 \%$ to total household income.
\end{abstract}

Keywords : Food Security, production, contribution, yard farming

\section{PENDAHULUAN}

Ketahanan pangan (food security) adalah kondisi terpenuhinya pangan bagi setiap rumah tangga yang tercermin dari tersedianya pangan yang cukup baik jumlah maupun mutunya, aman, merata dan terjangkau, pemantapan ketahanan pangan dapat dilakukan melalui pemantapan ketahanan pangan di tingkat rumah tangga. Dalam rangka mendukung empat kunci sukses pembangunan pertanian di Indonesia, Kementerian Pertanian telah meluncurkan berbagai program yang didukung dengan upaya percepatan dan penyebarluasan secara masif. Program yang mendukung upaya diversifikasi pangan dan peningkatan ketahanan pangan nasional salah satunya adalah melalui pengembangan Kawasan Rumah Pangan Lestari (KRPL).

Penataan pekarangan bertujuan untuk memperoleh manfaat yang sebesar-besarnya melalui pengelolaan lahan pekarangan secara intensif dengan tata letak sesuai dengan pemilihan komoditas dan keindahan lingkungan. Komoditas yang dipilih untuk setiap rumah tangga sebaiknya disesuaikan dengan kebutuhan keluarga, yaitu mempertimbangkan pemenuhan kebutuhan pangan dan gizi keluarga, serta kemungkinan pengembangannya secara komersial berbasis kawasan.

Wilayah penelitian Desa Mekar Sari Kecamatan Serawai merupakan desa yang belum mengoptimalkan pekarangan, belum memaksimalkan pengembangan pertanian dan kurangnya pengetahuan mengenai manfaat dan intensifikasi pekarangan yang bertujuan untuk mendapatkan manfaat. Masyarakat hanya 
menanam turun temurun yang sudah ada seperti pohon, buah-buahan. Pemanfaatan pekarangan dengan program Kawasan Rumah Pangan Lestari (KRPL) di kecamatan Serawai diharapkan dapat memberikan perubahan baik dari aspek sosial, ekonomi maupun lingkungan ditingkat rumah tangga petani serta meningkatkan aktivitas ekonomi masyarakat.

Adapun beberapa permasalahan dalam penelitian ini adalah sebagai berikut :

a. Bagaimana penerapan pengelolaan Kawasan Rumah Pangan Lestari (KRPL) di Desa Mekar Sari?

b. Berapa hasil produksi petani pada program Kawasan Rumah Pangan Lestari (KRPL) di Desa Mekar Sari?

c. Berapa total pendapatan rumah tangga petani di Desa Mekar Sari?

d. Bagaimana kontribusi hasil program Kawasan Rumah Pangan Lestari (KRPL) terhadap pendapatan rumah tangga petani di Desa Mekar Sari?

Sehingga tujuan dari penelitian ini adalah untuk mengetahui kontribusi hasil program Kawasan Rumah Pangan Lestari (KRPL) terhadap pendapatan rumah tangga petani di Desa Mekar Sari.

\section{METODE PENELITIAN}

Metode penelitian yang akan digunakan adalah metode survey dan pengamatan langsung. Penelitian ini menggunakan pendekatan kuantitatif dan kualitatif. Pendekatan kualitatif digunakan untuk mengevaluasi serta melihat dampak dari program Rumah Pangan Lestari terhadap pendapatan rumah tangga petani dengan memberikan gambaran deskriftif dari data yang muncul. Pendekatan kuantitatif digunakan untuk mengetahui besarnya pendapatan petani.

Penelitian ini dilakukan di Desa Mekar Sari Kecamatan Serawai Kabupaten Sintang Provinsi Kalimantan Barat. Pemilihan dilakukan dengan sengaja (Purposive) dengan pertimbangan Desa Mekar Sari Kecamatan Serawai Kabupaten Sintang merupakan kecamatan pelaksana program Kawasan Rumah Pangan Lestari (KRPL), dan penelitian ini akan dilakukan mulai bulan Maret sampai dengan April 2018.

Sumber data yang digunakan dalam penelitian ini berasal dari data primer dan data sekunder. Data primer adalah data yang diperoleh secara langsung dari sampel melalui penyebaran kuisioner dan wawancara terhadap responden dengan menggunakan daftar pertanyaan yang terkait dengan materi penelitian. Sedangkan data sekunder yang digunakan untuk mendukung data primer diperoleh melalui penelusuran hasil-hasil penelitian yang telah dilakukan oleh peneliti terdahulu, studi kepustakaan seperti literatur/referensi yang terkait dan dokumen yang relevan dengan penelitian ini.

Variabel yang diamati merupakan data dan informasi mengenai usaha tani Rumah Pangan Lestari (RPL) yang diusahakan oleh petani di daerah penelitian pada satu musim tanam. Variabel-variabel pengamatan yang digunakan dalam penelitian ini adalah sebagai berikut:

1. Jenis tanaman program RPL, adalah beberapa jenis organisme yang dibudidayakan pada suatu ruang atau media untuk dipanen pada masa ketika sudah mencapai tahap pertumbuhan tertentu

2. Luas lahan adalah keseluruhan wilayah yang menjadi tempat penanaman atau mengerjakan proses penanaman, luas lahan menjamin jumlah atau hasil yang akan diperoleh petani, Mubyarto (1995) 
3. Pendapatan usahatani adalah penerimaan dikurangi dengan biaya-biaya yang dikeluarkan untuk kegiatan usahatani ( $\mathrm{Rp} / \mathrm{m}$ panen),

4. Biaya usaha tani, merupakan biaya yang dikeluarkan petani untuk usaha tani dalam satuan rupiah ( $\mathrm{Rp} / \mathrm{m}$ panen).

\section{HASIL DAN PEMBAHASAN}

Desa Mekar Sari adalah salah satu desa pemekaran dari desa Batu Betung, dimana Letak Geografi kantor desa Mekar sari adalah berada di Lintang 0.34 dan bujur 112.4214 serta ketinggian 75. Desa Mekar Sari memiliki luas wilayah sebanyak $130 \mathrm{Ha}$ yang terdiri dari tanah pekarangan seluas $20 \mathrm{Ha}$, tanah sawah seluas 40 Ha, dan tanah tegal seluas $70 \mathrm{Ha}$.

Karakteristik Responden

Tabel 1. Karakteristik Responden

\begin{tabular}{lcc}
\hline Variabel Sosio-Demografi & Frekuensi (Orang) & Presentase (\%) \\
\hline Umur Responden & 2 & \\
$\leq 25$ tahun & 5 & 4 \\
$\leq 26-29$ tahun & 25 & 10 \\
$\leq 30-39$ tahun & 15 & 50 \\
$\leq 40-49$ tahun & 3 & 30 \\
$\quad \geq 50$ tahun & & 7 \\
Pendidikan Terakhir & 6 & 12 \\
Tidak tamat SD & 5 & 10 \\
SD & 16 & 32 \\
SLTP & 22 & 44 \\
SLTA & 1 & 2 \\
D3 & 2 & \\
Jumlah Anggota Keluarga & 21 & 4 \\
$\leq 3$ Orang & 27 & 42 \\
4-5 Orang & & 54 \\
$\geq 6$ Orang & 9 & 18 \\
Luas Lahan Pekarangan & 26 & 52 \\
$<25 \mathrm{M}^{2}$ & 13 & 26 \\
$25-40 \mathrm{M}^{2}$ & 2 & 4 \\
$41-50 \mathrm{M}^{2}$ & & \\
$>51 \mathrm{M}^{2}$ & & \\
\hline
\end{tabular}

Sumber: Data Primer, 2018

Dari tabel 1 dapat diketahui bahwa dari 38 responden, frekuensi terbesar karakteristik responden berdasarkan umur adalah umur 30-39 tahun sebanyak 25 orang atau sebesar 50\%. Secara umum responden memiliki tingkat pendidikan tamatan SLTA, hal ini disebabkan bahwa anggapan biaya pendidikan masih mahal dan keinginan untuk bersekolah masih rendah. Berdasarkan data diatas dapat disimpulkan bahwa 27 orang atau 54\% responden mempunyai beban tanggungan keluarga yang cukup banyak yaitu $\geq 6$ orang. Beban tanggungan yang banyak membuat responden mengurangi biaya produksi dalam pengelolaan usaha tani yang dilakukan, sehingga sebagian besar petani masih mengandalkan alam dan menggunakan cara yang tradisional. Luas lahan yang dimanfaatkan oleh responden untuk program KRPL ini adalah yang terbesar 52\% dengan luas lahan antara 25-40 $\mathrm{m}^{2}$ dan persentase luas lahan yang dimanfaatkan untuk KRPL 
terkecil sebesar 4\% namun dengan luas yang terbesar dengan luas lahan diatas 50 $\mathrm{m}^{2}$. Luas lahan yang dimanfaatkan untuk KRPL yang memiliki luasan terkecil adalah di bawah $25 \mathrm{~m}^{2}$ dan memiliki persentase 18 dari keseluruhan responden.

\section{Pengelolaan KRPL di Desa Mekar Sari}

\section{- Tahap Persiapan}

Tahap Persiapan persiapan program KRPL adalah:

1. Badan Ketahanan Pangan dan Perikanan Kabupaten Sintang selaku penanggung jawab pelaksanaan KRPL menyusun petunjuk Teknis (juknis) berdasarkan Petunjuk pelaksanaan (juklak) dari Badan Ketahanan Pangan dan perikanan Provinsi kalimantan Barat sebagai acuan untuk pelaksanaan KRPL di kabupaten.

2. Pengumpulan informasi awal tentang kelompok sasaran,

3. Pertemuan dengan dinas terkait untuk mencari ksepakatan dalam penentuan calon kelompok sasaran dan lokasi.

4. Memilih pendamping yang menguasai teknik pemberdayaan masyarakat sesuai dengan kriteria yang telah ditentukan.

\section{- Pembentukan Kelompok}

Kelompok sasaran adalah rumah tangga atau kelompok wanita tani dimana dalam 1 kelompok terdiri dari 25 orang wanita tani yang berdomisili berdekatan dalam satu kawasan sehingga dapat membentuk kawasan pekarangan dengan konsep KRPL. Untuk penelitian ini dipilih dusun Batu Meja dengan pertimbangan Dusun ini memiliki penduduk yang memiliki lahan perkarangan yang cukup untuk pengembangan KRPL serta dusun ini letaknya strategis karena merupakan lalulintas masyarakat dari desa - desa sekitar Mekar Sari, hal ini bertujuan untuk menjadikan dusun Batu meja percontohan dan simulator agar penduduk dusun maupun desa lain untuk mencoba memanfaatkan perkarangan walaupun dengan swadaya. Untuk menentukan kelompok penerima KRPL ini melalui mekanisme sebagai berikut:

1. Aparat kabupaten melakukan identifikasi CPCL berkoordinasi dengan BPP Kecamatan untuk memilih lokasi desa dan kepala desa untuk memilih kelompok yang memenuhi kriteria sesuai dengan petunjuk teknis KRPL,

2. Selanjutnya Calon Penerima dan Calon Lokasi ( CPCL ) tersebut ditetapkan melalui keputusan Kepala Badan Ketahanan Pangan dan Perikanan Kabupatn Sintang.

\section{- Sosialisasi}

Sosialisasi kegiatan dilaksanakan oleh tim teknis KRPL Badan Ketahanan Pangan dan Perikanan kabupaten Sintang kepada Pengurus Kelompok Wanita Tani serta seluruh anggotanya, dan PPL pendamping desa Mekar Sari Tahun 2017 di balai pertemuan desa. Sosialisasi bertujuan menyampaikan maksud dan tujuan kegiatan serta membuat ksepakatan awal untuk rencana tindak lanjut yangkan dilakukan.

\section{- Penguatan Kelembagaan kelompok} yakni:

Kegiatan ini dilaksanakan untuk menguatkan kemampuan kelompok

1. Untuk mampu mengambil keputusan bersama malalui musyawarah

2. Mampu untuk menaati keputusan yang telah ditetapkan

3. Mampu mencari dan memanfaatkan informasi 
4. Mampu bekerjasama dalam kelompok

5. Mampu bekerjasama dengan aparat maupun masyarakat lainnya.

\section{- Perencanaan kegiatan}

Kegiatan ini dilaksanakan untuk merencanakan rancang bangun pemanfaatan pekarangan dengan menanam berbagai tanaman sayuran, kegiatan dilaksanakan bersama-sama dengan kelompok wanita tani.

\section{- Pelatihan}

Pelatihan dilaksanakan sebelum pelaksanaan dilapangan, jenis pelatihan yang diberikan yaitu Anggteknik budidaya tanaman sayuran, pembenihan dan pembibitan, manfaat tanaman organik serta bahayanya dampak pestisida. Pelatihan ini diberikan kpada seluruh anggota kelompok wanitatani yang menerima program KRPL.

\section{- Pelaksanaan}

Tahap pelaksanaan meliputi:

1. Pembukaan lahan untuk lokasi persemaian, menyiapkan media tumbuh dan melakukan penyemaian dilahan yang sudah disediakan. Perawatan tanaman dilakukan secara bergantian dengan mengatur jadwal oleh anggota kelompok dan dilakukan sesuai arahan dari PPL pendamping.

2. Setelah tanaman siap dipindahkan ke polybag / media lainnya, selanjutnya dibagikan ke masing masing aggota kelompok dengan jenis dan jumlah sesuai RKKA kelompok.

3. Anggota yang sudah mendapat bibit tersebut akan melakukan penanaman baik dalam wadah polybag maupun langsung ke tanah, tergantung situasi halam mereka.

Setelah tanaman siap dipanen, hasilnya selain untuk kebutuhan rumah tangga anggota juga dijual untuk menambah penghasilan keluarga.

\section{- Pembiayaan}

Anggaran KRPL diperoleh berasal dari APBD, dimana pembiayan ini sudah di konversikan dalam bentuk benih dan pupuk. Selebihnya untuk pengembangan perkarangan anggota kelompok seperti pembuatan pagar, sarana budidaya, sarana pembuatan pupuk organik bersumber dari pembiayaan kelompok dan masing masing anggota.

\section{- Monitoring dan evaluasi}

Monitoing dilaksanakan untuk mengetahui perkembangan pelaksanaan kegiatan dan menilai kesesuaian kegiatan yang telah dilaksanakan dengan perencanaan. Evaluator dapat dibentuk oleh kelompok yang juga berfungsi sebagai motivator bagi anggota KWT. Kegiatan monitoring dilaksanakan secara bersama-sama untuk mengevaluasi semua kegiatan yang dimulai dari pengoahan tanah, penanaman hingga pasca panen. 
Hasil Produksi KRPL di Desa Mekar Sari

Hasil produksi KRPL di desa Mekar Sari dapat kita lihat pada tabel dibawah ini: Tabel 2. Hasil Produksi KRPL

\begin{tabular}{ccc}
\hline Komoditi KRPL & Total Produksi $(\mathrm{Kg})$ & $\begin{array}{c}\text { Rata-rata Produksi } \\
(\mathrm{Kg}) / \mathrm{Rt}\end{array}$ \\
\hline Sawi & 1.135 & 22,7 \\
Bayam & 953 & 19,06 \\
Kangkung & 1.201 & 24,02 \\
Tomat & 718 & 14,36 \\
Cabe & 511 & 10,22 \\
\hline Jumlah & 4.518 & 90,36 \\
\hline
\end{tabular}

Sumber: Data Primer, 2018.

Berdasarkan tabel 2 bahwa produksi yang dihasilkan dari program KRPL di Desa Mekar Sari Kecamatan Serawai Kabupaten Sintang untuk komoditi Sawi sebesar rata-rata $22,7 \mathrm{Kg}$ dengan harga rata-rata per Kg sebesar Rp. 14.960,-, komoditi Bayam sebesar rata-rata $19,06 \mathrm{Kg}$ dengan harga rata-rata per $\mathrm{Kg}$ sebesar $\mathrm{Rp}$. $10.000,-$, komoditi Kangkung sebesar rata-rata $24,02 \mathrm{Kg}$ dengan harga rata-rata per Kg sebesar Rp. 10.000,-, komoditi Tomat sebesar rata-rata 14,36 Kg dengan harga rata-rata per $\mathrm{Kg}$ sebesar Rp. 16.680,-, komoditi Cabe sebesar rata-rata 10,22 $\mathrm{Kg}$ dengan harga rata-rata per Kg sebesar Rp. 51.720,-, dengan total penerimaan sebesar rata-rata Rp. 1.526.420,-.

\section{Penerimaan}

Untuk penerimaan dari program KRPL di Desa Mekar Sari dapat kita lihat pada tabel dibawah ini:

Tabel 3. Penerimaan KRPL

\begin{tabular}{|lrrrrrrrr}
\hline Komoditas & \multicolumn{1}{l}{ Sawi } & \multicolumn{2}{c}{ Bayam } & \multicolumn{2}{l}{ Kangkung } & \multicolumn{2}{l}{ Tomat } & \multicolumn{2}{l}{ Cabe } & \multicolumn{2}{l}{ Jumlah } \\
\hline Produksi (kg) & $22, ?$ & 19,05 & 24,02 & 14,36 & 10,22 & 90,35 \\
\hline Harga/kg (Rp) & 15.000 & 10.000 & 10.000 & 17.000 & 50.000 & 102.000 \\
\hline Penerimaan & 340.500 & 190.60 & 240.20 & 244.12 & 511.00 & 1.526 .42 \\
\hline
\end{tabular}

Sumber: Data Primer 2018

Penerimaan dari Program KRPL komoditi Bayam sebesar rata-rata adalah Rp. 190.600,- komoditi Sawi sebesar rata-rata adalah Rp. 340.500,- komoditi Kangkung sebesar rata-rata adalah Rp. 109.200,- komoditi Tomat sebesar rata-rata adalah Rp. 240.200,- komoditi Cabe sebesar rata-rata adalah Rp. 511.000,- dengan total penerimaan dari hasil penjualan rata-rata adalah Rp. 1.526.420,-

\section{Biaya Produksi}

Biaya produksi dari usaha tani Program KRPL adalah biaya yang dikeluarkan pada saat pelaksanaan usaha tani KRPL dilakukan. Biaya produksi dari usahatani KRPL dapat dilihat dalam tabel berikut: 
Tabel 4. Biaya Produksi dari Usaha Tani KRPL

\begin{tabular}{|l|r|r|}
\hline Komoditas & Jumlah (Rp) & Rata-rata (Rp) \\
\hline Total Biaya Benih (Rp) & 11.563 .140 & 231.263 \\
\hline Total Biaya Pupuk (Rp) & 168.500 & 3.370 \\
\hline Biaya Penyusutan Alat Pertanian (Rp) & & 31.600 \\
\hline Parang & 1.580 .000 & 11.440 \\
\hline Cangkul & 572.000 & 2.508 \\
\hline Hand Spray & 125.400 & 12.950 \\
\hline Karung & 647.500 & 52.460 \\
\hline Biaya Tenaga Kerja/Hok (Rp) & & 48.160 \\
\hline Persiapan Lahan & 2.623 .000 & 35.840 \\
\hline Penanaman & 2.408 .000 & 33.280 \\
\hline Penyiangan & 1.792 .000 & 71.380 \\
\hline Pemupukan & 1.664 .000 & 46.080 \\
\hline Panen & 3.569 .000 & 580.331 \\
\hline Pasca Panen & 2.304 .000 & \\
\hline Total & 29.016 .540 & \\
\hline Sumber: Data Primer & & \\
\hline
\end{tabular}

Sumber: Data Primer, 2018.

Berdasarkan tabel 4 bahwa biaya produksi dari Program KRPL rata-rata adalah sebesar Rp. 580.331,- yang terdiri dari biaya tenaga kerja, biaya benih, pupuk, dan biaya penyusutan alat Pertanian.

\section{Pendapatan}

Pendapatan responden digolongkan menjadi tigayaitu pendapatan yang berasal dari usaha pertanian, pendapatan dari usaha non KRPL, pendapatan dari usahatani KRPL.

a) Pendapatan Pertanian

Pendapatan pertanian yang dimaksud dalam penelitian ini adalah penghasilan yang diterima responden dari pertanian selama satu bulan yang diwujudkan dalam bentuk rupiah. Pendapatan pertanian selama satu bulan. Pendapatan yang diperoleh dari pertanian selain pertanian KRPL, namun untuk lebih jelasnya dapat dilihat pada tabel 5 berikut ini:

Tabel 5. Pendapatan Rumah Tangga Pertanian

\begin{tabular}{ccc}
\hline Sumber Pendapatan Rumah Tangga (Rp) & Jumlah & Rata - Rata \\
\hline Perkebunan & $11,400,000$ & 228 \\
Sawah / Ladang & $10,600,000$ & 212 \\
Palawija & $12,940,000$ & 258,8 \\
Hortikultura & $15,870,000$ & 317,4 \\
Ternak & $7,100,000$ & 142 \\
Wirausaha & $13,800,000$ & 276 \\
Karyawan & $28,800,000$ & 576 \\
Perangkat Desa & $7,200,000$ & 144 \\
Buruh & $26,400,000$ & 528 \\
Angkutan & $22,300,000$ & 446 \\
Lain-lain & $2,700,000$ & 54 \\
\hline Total Pendapatan & $159,110,000$ & $3,182,200$ \\
\hline
\end{tabular}

Sumber: data primer, 2018 
Berdasarkan tabel 5 diatas dapat disimpulkan bahwa secara umum pendapatan berasal dari Rumah Tangga pertanian selain KRPL dan hal ini menunjukkan juga bahwa hasil panen masih dipergunakan untuk memenuhi kebutuhan pribadi dan dijual untuk membeli kebutuhan lainnya guna kelangsungan hidup responden. Kegiatan dari usaha tani didaerah penelitian ini dilakukan petani untuk keperluan menambah pendapatan yang diterima sehingga dapat memenuhi kebutuhan dalam rumah tangga.

b) Pendapatan dari Usahatani KRPL

Pendapatan usahatani KRPL adalah pendapatan yang diperoleh responden dari usaha tani KRPL perbulan dan dinyatakan dalam rupiah. Pendapatan ini merupakan pendapatan bersih usaha tani KRPL yang berasal dari penerimaan hasil penjualan hasil produksi dikurangi dengan biaya produksi selama sebulan dalam satuan rupiah. Pendapatan dari usaha tani KRPL dapat dilihat dalam tabel 6 berikut ini:

Tabel 6. Pendapatan Usaha Tani KRPL

\begin{tabular}{llllll}
\hline Keterangan & $\begin{array}{c}\text { Luas } \\
\text { Lahan } \\
(\mathrm{m} 2)\end{array}$ & $\begin{array}{c}\text { Biaya } \\
\text { Total (Rp) }\end{array}$ & $\begin{array}{c}\text { Penerimaan } \\
(\mathrm{Rp})\end{array}$ & $\begin{array}{c}\text { Pendapatan/ } \\
\text { Musim } \\
\text { Tanam }(\mathrm{Rp})\end{array}$ & $\begin{array}{c}\text { Pendapatan } \\
\text { Perbulan } \\
(\mathrm{Rp})\end{array}$ \\
\hline Jumlah & 1.744 & 29.016 .540 & 76.321 .000 & 47.304 .460 & 23.652 .230 \\
Rata-rata & 35 & 580.331 & 1.526 .420 & 946.089 & 473.045 \\
\hline
\end{tabular}

Sumber: Data Primer, 2018.

Dari table 6 diatas menunjukan bahwa pendapatan petani yang mengikuti program KRPL dengan melihat Total penerimaan yang diterima setelah dijual di kurangi dengan Total biaya rata-rata dikeluarkan maka didapatkan hasil penerimaannya rata-rata sebesar Rp. 1.526.420,-.

c) Total Pendapatan Rumah Tangga Petani Total pendapatan rumah tangga responden dalam penelitian ini adalah seluruh pendapatan yang diterima oleh responden dalam kurun waktu satu bulan dan dinyatakan dalam rupiah. Total pendapatan rumah tangga merupakan hasil seluruh pendapatan bersih dari pendapatan usahatani KRPL, pendapatan dari luar usaha tani non pertanian dan pendapatan dari pertanian dapat dilihat dari tabel 7 berikut ini:

Tabel 7. Total Pendapatan Rumah Tangga

\begin{tabular}{l|rrr}
\hline Keterangan & $\begin{array}{c}\text { Pendapatan Rumah Tangge. } \\
\text { Diluar KRPL (Rp) }\end{array}$ & $\begin{array}{c}\text { Pendapatan Rumah Tangga } \\
\text { KRPL (Rp) }\end{array}$ & Total Pendapatan \\
\hline Jumlah & 159.110 .000 & 23.652 .230 & 182.762 .230 \\
\hline Rata-rata & 3.182 .200 & 473.045 & 3.655 .245 \\
\hline
\end{tabular}

Sumber: data primer 2018.

Berdasarkan tabel 4.7 diatas menunjukan bahwa pendapatan petani yang mengikuti program KRPL dengan melihat Total penerimaan yang diterima setelah dijual dikurangi dengan Total biaya rata dikeluarkan maka didapatkan hasil penerimaannya adalah rata-rata sebesar Rp. 473.045,--

\section{Kontribusi}

Kontribusi dari Usahatani terhadap total pendapatan Rumah Tangga Responden. Kontribusi yang dimaksud dalam penelitian ini adalah sumbangan dari usahatani KRPL yang dilakukan didaerah penelitian sebanyak 50 petani yang berprofesi sebagai petani KRPL. Usahatani KRPL di Desa Mekar Sari Kecamatan Serawai 
Kabupaten Sintang diusahakan oleh para petani untuk memperoleh pendapatan. Selain dari usahatani KRPL para petani di Desa Mekar Sari juga memperoleh pendapatan dari usaha selain usaha tani Program KRPL. Pendapatan rumah tangga dari usaha lain diperoleh dari hasil Bekebun dan upah jasa lainnya, berternak atau lain sebagainnya baik yang dikerjakan kepala keluarga maupun anggota keluarga. Pendapatan total rumah tangga disini dapat dihitung dari pendapatan usaha tani tembakau, Pendapatan pertanian dan Pendapatan diluar usaha tani Program KRPL non pertanian. Untuk lebih jelasnya besarnya kontribusi usaha tani Proram KRPL dapat dilihat dalam tabel 8 berikut ini:

Tabel 8. Kontribusi Usaha Tani Program KRPL terhadap Pendapatan Rumah Tangga

\begin{tabular}{lcc}
\hline \multicolumn{1}{c}{ Sumber Pendapatan } & $\begin{array}{c}\text { Jumlah Pendapatan } \\
(\mathbf{R p})\end{array}$ & $\begin{array}{c}\text { Kontribusi } \\
(\mathbf{\%})\end{array}$ \\
\hline Total Pendapatan UsahaTani KRPL & 23.652 .230 & $14,87 \%$ \\
Total Pendapatan RT Petani & 159.110 .000 & \\
\hline
\end{tabular}

Sumber: Data Primer, 2018.

Kontribusi usaha tani Proram KRPL terhadap pendapatan total rumah tangga adalah Rp. 23.652.230,- atau rata-rata sebesar Rp. 473.045,-. Sedangkan Total Pendapatan Rumah tangga Petani adalah sebesar Rp. 159.110.000,- atau atau rata-rata Rp.3.182.200,-. Untuk kontribusi sebesar 14.87\%. Hal ini menunjukkan adanya kontribusi Pendapatan rumah tangga petani berasal dari usahatani KRPL untuk menambah pendapatan diluar usahatani non KRPL. Usahatani KRPL memberikan kontribusi terhadap Pendapatan total rumah tangga petani,dan pendapatan tersebut digunakan petani untuk memenuhi kebutuhan keluarga, seperti biaya makan sehari-hari, biaya sekolah anak dan lain sebagainya.

Kontribusi adalah sesuatu yang diberikan bersama-sama dengan pihak lain untuk tujuan biaya atau kerugian tertentu atau bersama (Guritno, 1992:76). Sedangkan dalam Kamus Besar Bahasa Indonesia (2008:752) kontribusi dapat diartikan sebagai sebagai sumbang. Maka, dalam kaitannya dengan program KRPL di Desa Mekar Sari Kecamatan Serawai Kabupaten Sintang dalam pengembangan pemanfaatan lahan perkarangan, dapat disimpulkan bahwa kontribusi yaitu sumbangan yang diberikan dari tanaman sayuran yang mengikuti Program KRPL yang terdiri dari Sawi, Bayam, Kangkung, Tomat dan Cabe. Pengukuran kontribusi dapat dilakukan dengan indikator sebagai berikut:

$\begin{array}{ll}\text { Lebih dari 50\% } & \text { : Sangat Baik } \\ 40 \%-50 \% & \text { : Baik } \\ 30 \%-40 \% & \text { : Sedang } \\ 20 \%-30 \% & \text { : Cukup } \\ 10 \%-30 \% & \text { : Kurang } \\ \text { Kurang dari } 10 \% & \text { : Sangat Kurang. }\end{array}$

Berdasarkan indikator pengukuran kontribusi tersebut maka semakin baik kriteria kontribusi Program KRPL, maka semakin besar kontribusi penerimaan petani yang mengikuti Program KRPL terhadap total penerimaan rumah tangga Petani (Halim, 2004:163). Jika dilihat dari indikator tersebut maka kontribusi Program KRPL di Desa Mekar Sari Kecamatan Serawai Kabupaten Sintang kurang berhasil karena hanya $14,87 \%$ dari hasil perhitungan tersebut. Tujuan dari adanya 
program KRPL adalah untuk memberikan tambahan pendapatan Rumah Tangga petani dan pemanfaatan lahan perkarangan sudah tercapai.

\section{KESIMPULAN DAN SARAN Kesimpulan}

Program KRPL merupakan himpunan beberapa rumah tangga dan memanfaatkan perkarangan untuk bertananam 5 komoditi sayuran yaitu kangkung, sawi, bayam, cabe dan tomat. Pengelolaan rumah tangga dan produksi usahatani pada program Kawasan Rumah Pangan Lestari (KRPL) di Desa Mekar Sari dilaksanakan cukup baik dilihat dari adanya penambahan pendapatan petani program KRPL untuk kesejahteraan keluarga. Kontribusi program Kawasan Rumah Pangan Lestari (KRPL) terhadap pendapatan rumah tangga petani di Desa Mekar Sari memberikan kontribusi $14,87 \%$ terhadap pendapatan total rumah tangga.

\section{Saran}

Usahatani dengan pemanfaatan lahan pekarangan merupakan potensi yang sangat baik untuk dikembangkan. Perlunya peran penyuluh untuk meningkatkan kegiatan yang menambah pengetahuan dan skil petani seperti: pelatihan-pelatihan dalam berusahatani (bercocok tanam yang baik) dan pelatihan dalam menghadapi permasalahan usahatani. Adanya pelatihan tersebut maka petani mampu menerima informasi dan inovasi terbaru sebagai motivasi mereka dalam melakukan kegiatan usahatani KRPL tersebut. Dan melihat hasil penelitian bahwa pendapatan petani meningkat setelah mengikuti program KRPL, (petani mampu menekan angka pengeluaran konsumsis ayur-sayuran), maka diharapkan pihak pemerintah Kabupaten Sintang untuk lebih mengoptimalkan program KRPL tersebut dengan tujuan agar program KRPL lebih berkembang dan tetap terus berkelanjutan. Pada dasarnya program KRPL ini dapat dilakukan dengan mudah khususnya bagi anggota kelompok dan umumnya bagi masyarakat sekitar.

\section{DAFTAR PUSTAKA}

Agus, 2001.Memanfaatkan Lahan Pekarangan Sebagai Apotik Hidup. Penebar Swadaya. Jakarta.

Anita, A. 2005.Pengaruh Ibu Rumah Tangga yang Bekerja di Luar Sektor Pertanian Terhadap Pendapatan Keluarga. Studi Kasus : Desa Purwosari Kecamatan Tegalrejo Kabupaten Magelang. Semarang: Fakultas Ilmu Sosial Jurusan Pendidikan Ekonomi.

(http://digilib.unnes.ac.id/gsdl/collect/skripsi/indeks/assoc/HASHdaff.dir/doc.pdf, diakses pada tanggal 15 November 2014).

Anonim, 2009.Manfaatkan Pekarangan Rumah yang Sempit Menjadi Lahan Produktif.http://iconagry.com/2009/09/tekan-budaya-konsumtifmulailah.html diakses 15 November 2014.

Arikunto, S. 2006. Prosedur Penelitian Suatu Pendekatan Praktik. Rineka Cipta. Jakarta.

Ashari, dkk.2012. Potensi Dan Prospek Pemanfaatan Lahan Pekarangan Untuk Mendukung Ketahanan Pangan.Artikel.Bogor. Badan Pusat Statistik.Provonsi Kalbar. 2016.

Dinas Pertanian. Kabupaten Sintang. 2016. 
Ginting, M. 2010. Pekarangan Petani Dan Kemiskinan. Gadjah Mada University press. Yayasan Agroekonomika.

Guritno, 1992.Kamus Ekonomi (Bisnis \& Perbankan).Gadjah Mada University Press, Yogyakarta.

Handayani, M.2009. Kontribusi pendapatan ibu rumah tangga pembuat makanan olahan terhadap total pendapatan keluarga. Jurnal Kependudukan dan Pengembangan Sumber Daya Manusia.Volume V No. 1 Juli 2009.Jurusan Sosial Ekonomi Fakultas Pertanian Univ.Udayana.

Hernanto. 1991. Ilmu Usaha Tani. Penebar Swadaya. Jakarta.

Hernanto. 1994. Ilmu Usaha Tani. Penebar Swadaya. Jakarta. Mubiyarto. 1989. Pengantar Ekonomi Pertanian. LP3 ES. Jakarta. Noor, H.F. 2007.Ekonomi Manajerial.Rajawali Pers.Jakarta.

Nurmanaf, A. R. 2006. Peranan Sektor Luar Pertanian Terhadap Kesempatan Dan Pendapatan Di Pedesaan Berbasis Lahan Kering. Jurnal SOCA vol 8. no3. November 2008, hal 318-322.

Ranti, D. 2009. Peranan Program Pemberdayaan Pertanian Lembaga Amil Zakat (LAZ) Swadaya Ummah terhadap Peningkatan Pendapatan Petani di Kelurahan Kulim Kecamatan Tanayan Raya Kota Pekanbaru. Jurusan Sosial Ekonomi Pertanian Fakultas Pertanian UNRI. Pekanbaru.

Riah. 2005. Pemanfaatan Lahan Pekarangan. Penebar Swadaya. Jakarta.

Rohaidah, I. 2014. Pemanfaatan Lahan Pekarangan Sebagai Upaya Pemenuhan Kebutuhan Keluarga. Karya Tulis Ilmiah. Jurusan Agribisnis Universitas Siliwangi.Tasikmalaya.

Roza, Y.2012. Kontribusi Usahatani Lahan Pekarangan Terhadap Ekonomi Rumah Tangga Petani Di Kecamatan Kerinci Kabupaten Pelalawan.Volume 3, Nomor 2, Desember 2012.Riau.

Rusli. 1983. Perkembangan pertanian. Bali pustaka. Yogyakarta. Sapril,M.2012“Kontribusi Penerimaan Penjualan Limbah Kotoran Ternak Unggas Terhadap Penerimaan Total Peternak Ayam Petelur di Kec.Kulo Kab Sidrap.Skripsi. Universitas Muhamadiyah. Makasar.

Setiono. 2011. Intensifikasi lahan pekarangan. http://setiono774.com/2011/01/ intensifikasi-lahan-pekarangan.html.

Soeharjo, Dan Patong. 1973. Sendi-Sendi pokok Usahatani. Departemen Ilmu Ekonomi. Fakultas Ilmu Pertanian Bogor. Bogor.

Soekartawi.1991. Agribisnis Teori Dan Aplikasinya. PT. Raja. Grafindo Persada.Jakarta.

Soekartawi. 1986. Agribisnis Teori Dan Aplikasinya. PT. Raja. Grafindo Persada.Jakarta.

Sopiah, P. 2006. Menghijaukan Pekarangan Dengan Tanaman yang Bermanfaat PT Sinergi Pustaka. Jakarta. 